\title{
Human Peripheral Blood Monocytes Display Surface Antigens Recognized by Monoclonal Antinuclear Antibodies
}

\author{
v. Michael Holers and Brian L. Kotzin \\ Department of Medicine, Veterans Administration Medical Center and University of Colorado \\ Health Sciences Center, Denver, Colorado 80220
}

\begin{abstract}
We used monoclonal anti-nuclear autoantibodies and indirect immunofluorescence to examine normal human peripheral blood mononuclear leukocytes for the presence of cell surface nuclear antigens. Only one monoclonal anti-histone antibody (MH-2) was found to bind to freshly isolated PBL, staining $\sim 10 \%$ of large cells. However, after cells were placed into culture for 16$24 \mathrm{~h}$, a high percentage (up to $60 \%$ ) of large-sized cells were recognized by an anti-DNA (BWD-1) and several different antihistone monoclonal antibodies (BWH-1, MH-1, and MH-2). These antibodies recognize separate antigenic determinants on chromatin and histones extracted from chromatin. None of the monoclonal autoantibodies appeared to bind to a significant percentage of cells of relatively small cell size, either before or after culture. The histone antigen-positive cells were viable, and the monoclonal antibodies could be shown to be binding to the cell surface and not to the nucleus. Further experiments, including those using aggregated Ig to block antibody binding, strongly indicated that anti-histone antibody binding was not Fc receptor mediated. Using monoclonal antibodies specific for monocytes and $T$ cells, and complement-mediated cytotoxicity, the cells bearing histone antigens were shown to be primarily monocytes. The appearance of histone and DNA antigen-positive cells was nearly completely inhibited by the addition of low concentrations $(0.25 \mu \mathrm{g} / \mathrm{ml})$ of cycloheximide at initiation of the cultures. In contrast, little effect on the percentage of positive cells was detected if cells were exposed to high doses of gamma irradiation before culture. These data further support the existence of cell surface nuclear antigens on selected cell subsets, which may provide insight into the immunopathogenesis of systemic lupus erythematosus and related autoimmune diseases.
\end{abstract}

\section{Introduction}

Anti-nuclear antibodies (ANA) ${ }^{1}$ are present in high frequency in patients with systemic lupus erythematosus (SLE) and related autoimmune diseases. It is presently not known whether ANA

Dr. Kotzin is the recipient of a Clinical Investigator Award from the Veterans Administration. Address correspondence to Dr. Kotzin, Rheumatology Section. Dr. Holers's current address is Howard Hughes Medical Institute, Washington University Medical School, St. Louis, MO 63110.

Received for publication 29 October 1984 and in revised form 29 April 1985.

1. Abbreviations used in this paper: ANA, anti-nuclear antibodies; ELISA, enzyme-linked immunosorbent assay; FACS, fluorescence-activated cell sorter; FCS, fetal calf serum; PBL, peripheral blood mononuclear leukocytes; PHA, phytohemagglutinin; SLE, systemic lupus erythematosus.

The Journal of Clinical Investigation, Inc.

Volume 76, September 1985, 991-998 that are not involved in immune complex-mediated damage cause cell damage by binding to their respective nuclear antigen. Thus, antibodies to double-stranded DNA are implicated in the immune complex glomerulonephritis of SLE (1-3), but it is unknown whether antibodies to $\mathrm{Sm}$, ribonucleoprotein, SS-A/Ro, SS-B/La, histone, Scl-70, centromere, PM-1, Jo-1, etc. (4) result in cell damage through any mechanism. These antibodies have been associated with different clinical syndromes, which makes the question even more pathophysiologically relevant (4-12). There is little evidence that these antibodies readily penetrate living cell membranes and then effect cell damage by binding to the respective intranuclear antigen (13). We and others have hypothesized that nuclear antigens are selectively present on the plasma membrane of different cells. These nuclear antigens could then provide potentially important targets for ANA. The association of different ANA with different clinical syndromes could also occur at the level of antibody production, and involve cell surface nuclear antigens.

Other investigators have described the presence of DNA and histone on the surface of human peripheral blood mononuclear cells (PBL) obtained from normal individuals (14-21). These studies employed techniques that did not use antibodies (1417), or used sera from SLE patients that may have contained a multitude of specificities for both nuclear and nonnuclear antigens (18-21). We recently produced and characterized several monoclonal anti-histone and anti-DNA autoantibodies derived from murine models of lupus (22). Using indirect immunofluorescence techniques and the analyzing capabilities of the fluorescence-activated cell sorter (FACS), we now report that a small percentage of large cells from freshly isolated PBL stain positive with one anti-histone monoclonal antibody. Furthermore, after PBL are placed into short-term culture, a high percentage of large cells, identified to be primarily monocytes, express surface material recognized by several monoclonal antihistone antibodies and an anti-DNA antibody.

\section{Methods}

Isolation of mononuclear cells from peripheral blood. PBL were separated from heparinized blood on Ficoll-Hypaque gradients (Pharmacia Fine Chemicals, Piscataway, NJ) as previously described (23). Only blood from normal donors was used in the present experiments.

Monoclonal antibodies. Monoclonal anti-nuclear antibodies were produced by fusion of NZB/NZW or MRL/1 spleen cells (22). The characteristics and specificities of these antibodies have been recently described in detail (22). Antibody BWH-1 (IgG2a) recognizes the histone H2A$\mathrm{H} 2 \mathrm{~B}$ complex, but fails to bind to individual histones (i.e., $\mathrm{H} 1, \mathrm{H} 2 \mathrm{~A}$, $\mathrm{H} 2 \mathrm{~B}, \mathrm{H} 3$, or H4). Antibody MH-1 (IgM) binds to individual histones $\mathrm{H} 2 \mathrm{~A}, \mathrm{H} 2 \mathrm{~B}$, and $\mathrm{H} 3$, while $\mathrm{MH}-2$ (IgM) binds to $\mathrm{H} 2 \mathrm{~A}, \mathrm{H} 3$, and $\mathrm{H} 4$. Antibody BWD-1 (IgG2a) recognizes both single-stranded and doublestranded DNA. None of these antibodies demonstrate any rheumatoid factor activity. Culture supernatants of the cloned cell lines were used in the present experiments. The mouse IgG or IgM concentration in these supernatants was determined by an enzyme-linked immunosorbent 
assay (ELISA) technique (22). For some experiments, antibody BWH1 was further purified from culture supernatants by Sephadex G-200 gel filtration (22).

Control monoclonal antibodies of the same subclass and at the same Ig concentration as the anti-histone antibodies were used in every experiment. An IgG2a monoclonal antibody (RPC 5 or UPC 10) or IgM monoclonal antibody (TEPC 183) (all from Litton Bionetics, Inc., Charleston, SC) were added to culture supernatants of the nonsecreting parent myeloma line.

Anti-Leu-1, which recognizes nearly all peripheral blood $\mathrm{T}$ cells, was kindly provided by Dr. Ronald Levy (Stanford University Medical Center, Stanford, CA) (24). Antibody $3 \mathrm{Cl0}$, which recognizes nearly all peripheral blood monocytes, was kindly provided by Dr. Ralph Steinman (Rockefeller University, New York City) (25).

Cell cultures. PBL were cultured in RPMI-1640 medium supplemented with $10 \mathrm{mM}$ Hepes buffer, $2 \mathrm{mM}$ glutamine, $100 \mathrm{U} / \mathrm{ml}$ penicillin, and $100 \mu \mathrm{g} / \mathrm{ml}$ streptomycin (all from Gibco Laboratories, Grand Island, NY). In initial experiments, only small differences were observed when cultures containing $10 \%$ decomplemented pooled human sera were compared with those containing 10\% fetal calf serum (FCS) (Sterile Systems Inc., Logan, UT). For the experiments presented, cultures contained $10 \%$ FCS. Unless otherwise indicated, PBL were cultured at $10^{6}$ cells/ $\mathrm{ml}$ either in round bottom microculture plates (Flow Laboratories Inc., McLean, VA) (final volume of $0.2 \mathrm{ml} /$ well) or in culture tubes (model 2058, Becton-Dickinson \& Co., Oxnard, CA) (final volume of $1 \mathrm{ml} /$ tube). Cultures were incubated at $37^{\circ} \mathrm{C}$ in a $5 \% \mathrm{CO}_{2}$ humidified atmosphere.

In some experiments, PBL ( $1 \mathrm{ml}$ at $10^{6}$ cells $\left./ \mathrm{ml}\right)$ were enriched for monocytes by incubation on plastic plates (model 3524, Costar, Cambridge, MA) for $1 \mathrm{~h}$ at $37^{\circ} \mathrm{C}$. Nonadherent cells were gently washed off, and then $1 \mathrm{ml}$ of complete media was added back to the adherent cells. These cells were then cultured for $16 \mathrm{~h}$ as described above.

In some experiments, PBL were irradiated using a cobalt source (Gamma Cell, Atomic Energy Commission of Canada, Ottawa, Canada) immediately before culture. In separate experiments, cycloheximide (Sigma Chemical Co., St. Louis, MO) was added before culture or at various times after initiation of culture. In a few experiments, phytohemagglutinin (PHA) (Wellcome Reagents Unlimited, Beckenham, England) was added to cultures at $2 \mu \mathrm{g} / \mathrm{ml}$.

Immunofluorescent staining and analysis with the fluorescence-activated cell sorter (FACS). Freshly isolated PBL or cells harvested from cultures $\left(1 \times 10^{6}\right)$ were washed and resuspended in $0.1 \mathrm{ml}$ of phosphatebuffered saline (PBS) containing $0.05 \%$ azide and $1 \%$ FCS. Cells were reacted with saturation levels of the appropriate monoclonal antibody for $30 \mathrm{~min}$ at $4^{\circ} \mathrm{C}$. Unless otherwise indicated, the approximate amounts of added antibody per $10^{6}$ cells were as follows: BWH-1, $0.5 \mu \mathrm{g}$; MH-1, $1.0 \mu \mathrm{g} ; \mathrm{MH}-2,0.5 \mu \mathrm{g} ; \mathrm{BWD}-1,0.75 \mu \mathrm{g}$; Cont-IgG2a, 0.5-1.0 $\mu \mathrm{g}$; ContIgM, 0.5-1.0 $\mu \mathrm{g}$; Leu-1, $0.5 \mu \mathrm{g} ; 3 \mathrm{C} 10$, and $0.3 \mu \mathrm{g}$. After washing, the cells were reacted at saturation with a fluorescein-conjugated goat antimouse IgG (Tago, Inc., Burlingame, CA) or goat anti-mouse IgM (Kirkegaard and Perry Laboratories, Inc., Gaithersburg, MD) for an additional $30 \mathrm{~min}$. All IgG monoclonal antibodies and second-stage reagents were centrifuged in an airfuge (Beckman Instruments, Palo Alto, CA) at $>100,000 \mathrm{~g}$ before use. After washing, the labeled cells were analyzed in a fluorescence-activated cell sorter (FACS IV, Becton Dickinson Electronic Laboratories, Mountain View, CA) at $\sim 7.5 \times 10^{2}$ cells $/ \mathrm{s}$. The machine was standardized before each use for forward light scatter and for fluorescence intensity using commercially prepared microspheres and glutaraldehyde-fixed chicken erythrocytes (26). Scatter gates were set to exclude the majority of contaminating erythrocytes or dead cells as well as cell aggregates. Details concerning the staining technique and FACS analysis have been reported previously $(26,27)$.

Cell viability was determined by staining with fluorescein diacetate (Sigma Chemical Co.) at $10 \mu \mathrm{g} / \mathrm{ml}$ for $15 \mathrm{~min}$ at room temperature (26, 28 ). Using scatter gates described above, $>95 \%$ of freshly prepared PBL were intensely fluorescent after staining with fluorescein diacetate. Using the same staining techniques and the same fluorescence intensity thresholds, PBL treated for 20 min with $60 \%$ ethanol were $<1 \%$ positive.
Complement-mediated cytotoxicity. In some experiments, mononuclear cells harvested after culture were depleted of different cell subsets using complement-mediated cytotoxicity. After washing, cells at 5 $\times 10^{6} / \mathrm{ml}$ were first exposed to the appropriate monoclonal antibody (3C10 at $10 \mu \mathrm{g} / \mathrm{ml}$, anti-Leu-1 at $3 \mu \mathrm{g} / \mathrm{ml}$, or BWH-1 at $10 \mu \mathrm{g} / \mathrm{ml}$ ) for $45 \mathrm{~min}$ at $4^{\circ} \mathrm{C}$. After washing, cells were exposed to the appropriate dilution of rabbit complement (Pel Freez Biologicals, Rogers, AR) (prescreened for low background cytotoxicity and good support of complement-mediated killing) for $45 \mathrm{~min}$ at $37^{\circ} \mathrm{C}$. All reagents were diluted in a balanced salt solution containing $0.02 \%$ sodium azide. After washing, the remaining cells were stained and analyzed for fluorescence intensity with the FACS as described above. In all experiments, cells treated with antibody and complement were compared with those treated with complement alone.

Isolation of non-T cells from PBL. PBL were obtained from normal volunteers as described above and then enriched for non-T cells by a sheep erythrocyte rosetting technique. $5 \times 10^{6}$ cells $/ \mathrm{ml}$ were suspended in $40 \%$ FCS in PBS and mixed with an equal volume of $3 \%$ sheep erythrocytes (previously treated with 2-aminoethylisothiouronium bromide hydrobromide (Sigma Chemical Co.) in $40 \%$ FCS-PBS. The mixture was gently pelleted and maintained at $4^{\circ} \mathrm{C}$ for $1 \mathrm{~h}$. It was then sedimented over a Ficoll-Hypaque gradient (Pharmacia Fine Chemicals) in order to separate the rosetted $T$ cells from the nonrosetted cells. The nonrosetting fraction was then treated with anti-Leu- 1 and complement as described above. The remaining cells contained $<1 \%$ Leu- $1^{+}$cells as determined by indirect immunofluorescence and FACS analysis and demonstrated no proliferative response to PHA.

Preparation and blocking with aggregated human Ig. Aggregated human Ig was prepared from Cohn Fraction II (Sigma Chemical Co.) by heating at $63^{\circ} \mathrm{C}$ for $1 \mathrm{~h}$. Ig concentrations were estimated using a spectrophotometer. Freshly prepared PBL or cells harvested after culture were then incubated with different concentrations of aggregated Ig for 1 $\mathrm{h}$ at $4^{\circ} \mathrm{C}$ before immunofluorescent staining. Some cells were stained directly for the amount of human Ig binding using a fluorescein-conjugated goat anti-human IgG reagent (Tago, Inc.). The fluorescein-conjugated anti-mouse Ig antibodies (see above) demonstrated no crossreactivity with human Ig.

Absorption of anti-histone antibody activity. Chromatin was isolated from calf thymus and partially digested with trypsin as previously described (22). Culture supernatants containing BWH-1 $(5 \mu \mathrm{g} / \mathrm{ml})$ were incubated without antigen or with increasing concentrations (1-250 $\mu \mathrm{g} /$ $\mathrm{ml}$ ) of trypsinized chromatin or chromatin for $1 \mathrm{~h}$ at room temperature. The incubation mixture was then centrifuged in an airfuge (Beckman Instruments) at over $100,000 \mathrm{~g}$ for $15 \mathrm{~min}$. The supernatant was then used for immunofluorescent staining as described above. As a control for nonspecific absorption, antibody $3 \mathrm{Cl0}(3 \mu \mathrm{g} / \mathrm{ml})$, which recognizes nearly all peripheral blood monocytes, was absorbed in a similar fashion with trypsinized chromatin or chromatin.

Other materials. Sheep erythrocytes were conjugated with highly purified total histones using 1-ethyl-3-(3-dimethylaminopropyl) carbodiimide $\mathrm{HCl}$ as previously described (29). Conjugated cells stained intensely using anti-histone antibodies BWH-1, MH-1, and $\mathrm{MH}-2$, but no binding was detected using BWD-1.

\section{Results}

Binding of monoclonal anti-nuclear antibodies to PBL before and after culture. Human PBL from normal donors were analyzed for the presence of surface nuclear antigens using monoclonal anti-nuclear antibodies and indirect immunofluorescence techniques. Initial experiments were performed with BWH-1, an IgG2a monoclonal anti-histone antibody. This antibody was chosen because of its specificity for the histone complex H2A$\mathrm{H} 2 \mathrm{~B}$, and the lack of detectable cross-reactivity with other antigens tested (22). Positive cells with this antibody were not detected before in vitro culture of isolated PBL (see below). Fig. 1 


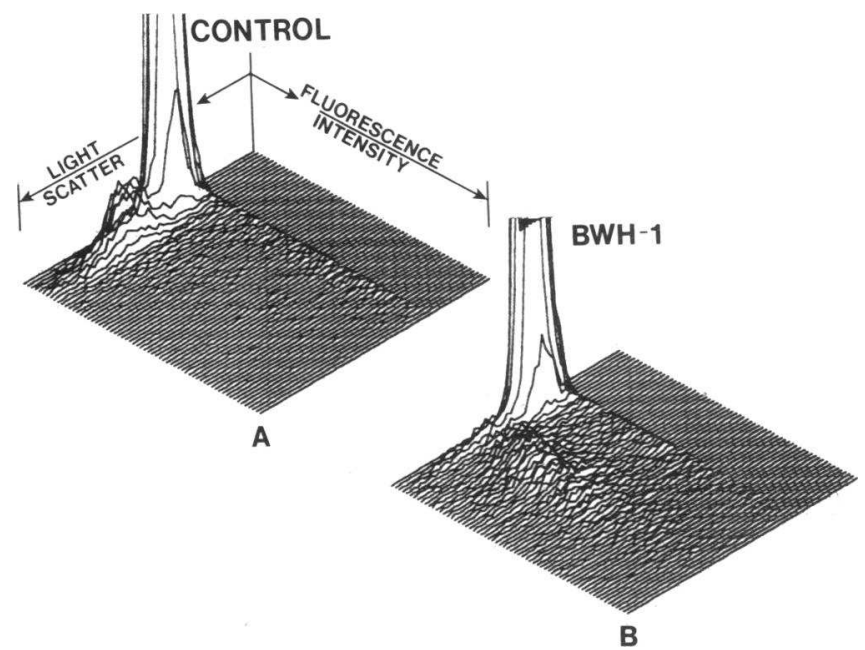

Figure 1. Three-dimensional computer analysis of human PBL studied after $20 \mathrm{~h}$ of culture. Cells were stained with either a control IgG2a monoclonal antibody $(A)$ or IgG2a anti-histone monoclonal antibody BWH-1 $(B)$ and a fluorescein-conjugated goat anti-mouse IgG antibody. $\mathrm{X}$ axis, intensity of fluorescence; $\mathrm{Y}$ axis, forward angle light scatter; $Z$ axis, cell number.

shows a computer analysis of one representative experiment in which cells were studied after $20 \mathrm{~h}$ of culture. Low angle light scatter tended to separate human PBL into two major viable cell fractions (probably mostly determined by cell size), with $13.7 \%$ of the total cells in this experiment in the fraction containing large cells. Using the same fluorescence intensity thresholds, $3.3 \%$ of the fraction containing large cells were positive with the control IgG2a antibody, while $52.5 \%$ were positive with BWH-1. In contrast, $<2 \%$ of the fraction containing small cells were positive with either antibody (Fig. 1). When the percentage of large cells is considered, $\sim 8 \%$ of the total cells were positive with BWH-1 in this representative experiment.

Antibody BWH-1, as well as $\mathrm{MH}-2$ (see below), bound to cultured large cells in a saturable manner. Thus, while $<5 \%$ of large cells were positive with $0.05 \mu \mathrm{g}$ antibody added per $10^{6}$ cells, $0.5 \mu \mathrm{g}$ stained $60 \%$ of the large cells. An additional fourfold increase in antibody concentration did not result in a further increase in percentage of positive cells nor an increase in the number of binding sites per positive cell (as determined by median channel of fluorescence intensity). The binding of BWH1 to large cells was also markedly decreased by prior absorption with increasing concentrations of trypsinized chromatin or intact chromatin, which contain in high concentration the determinant recognized by BWH-1. Absorbing with trypsinized chromatin at 5 and $50 \mu \mathrm{g} / \mathrm{ml}$ decreased binding to 27 and $2 \%$ positive large cells, respectively, compared with $51 \%$ positive cells without prior absorption. In contrast, binding of antibody $3 \mathrm{C} 10$, which recognizes nearly all peripheral blood monocytes, was unaffected by prior incubations with up to $250 \mu \mathrm{g} / \mathrm{ml}$ of trypsinized chromatin $(75 \%$ of large cells positive compared with $77 \%$ without prior absorption). For these studies, antibodies BWH-1 and $3 \mathrm{C} 10$ were used at similar points on the binding curve.

We studied the relationship between the time period of cell culture and the ability of BWH-1 to bind to cells in the large cell fraction. As shown in Fig. 2, few cells stain positive until after $6 \mathrm{~h}$ of culture. Over the next few hours there was a marked increase in the percentage of BWH-1-positive cells, and after 12

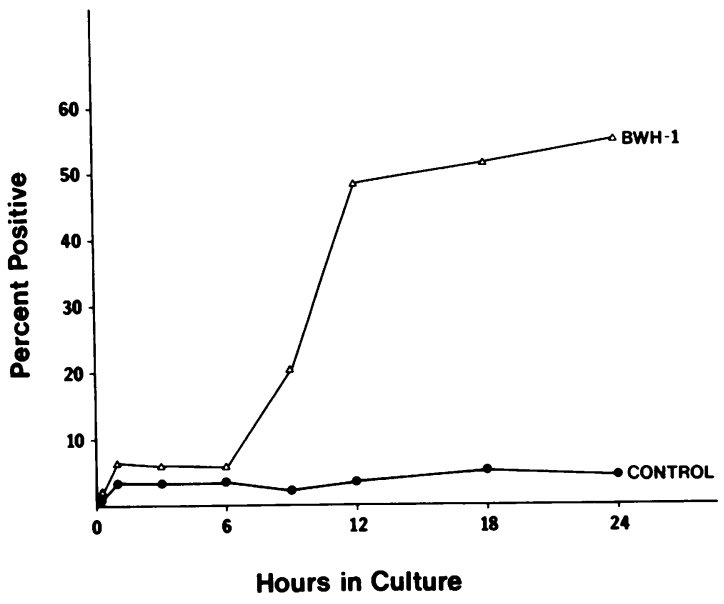

Figure 2. Kinetics of histone expression in culture. Data are presented as the percentage of positive cells in the large cell fraction for one representative experiment of three. PBL were cultured for the indicated period of time and then stained with an anti-histone monoclonal antibody (BWH-1) or a control IgG2a monoclonal antibody (control).

$\mathrm{h}$ the percentage of positive cells reached a plateau level of $\sim 50 \%$. In contrast, a minimal increase was observed using the control IgG2a antibody (Fig. 2). The percentage of cells in the large fraction changed little over the 24-h culture period.

We also analyzed cells before and after 16 to $24 \mathrm{~h}$ of culture using other anti-histone monoclonal antibodies and a monoclonal anti-DNA antibody. In multiple experiments, antibody BWH-1 (anti-H2A-H2B) failed to stain the large cells before culture, while nearly $50 \%$ were positive after culture (Table I). In contrast, $11.1 \%$ (range $2.8-25.3 \%$ ) of cells freshly isolated from peripheral blood were positive using $\mathrm{MH}-2$, which recognizes individual histones $\mathrm{H} 2 \mathrm{~A}, \mathrm{H} 3$, and $\mathrm{H} 4$ (Table I). This an-

Table I. Percentage of Histone and DNA Antigen-positive Cells in the Large Cell Fraction Before and After Culture

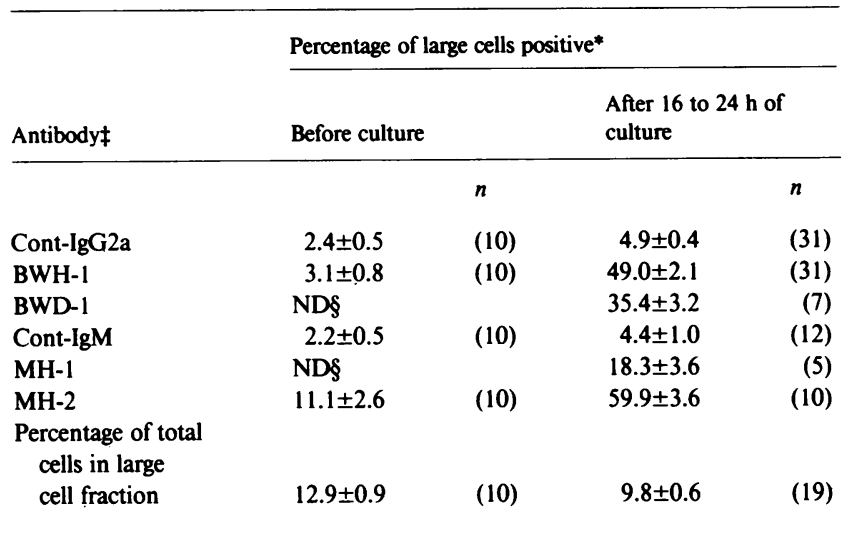

* Data are presented as the mean \pm SE for the number $(n)$ of experiments indicated before culture and after 16 to $24 \mathrm{~h}$ of culture, respectively. Cells from 10 different normal individuals were used for experiments involving BWH-1 and MH-2.

¥ BWH-1 (IgG2a) binds to the histone H2A-H2B complex and fails to recognize individual histones. BWD-1 (IgG2a) binds to both single-stranded and double-stranded DNA. MH-1 (IgM) binds to individual histones H2A, H2B, and $\mathrm{H} 3$, while $\mathrm{MH}-2$ (IgM) binds to individual histones $\mathrm{H} 2 \mathrm{~A}, \mathrm{H} 3$, and $\mathrm{H} 4$. $\mathrm{MH}-1$ and $\mathrm{MH}-2$ were studied at antibody concentrations that gave equal fluorescent staining on histone-conjugated sheep erythrocytes as well as equal binding in ELISA to chromatin.

$\S$ Not done. 
tibody also stained nearly $60 \%$ of the large cells after 16 to $24 \mathrm{~h}$ of culture. Kinetic experiments using MH-2 were similar to those using BWH-1 (see Fig. 2), showing both an increase in the number of positive cells as well as an increase in the fluorescence intensity of positive cells over $24 \mathrm{~h}$ of culture. Antibody $\mathrm{MH}-1$ (which recognizes different determinants on $\mathrm{H} 2 \mathrm{~A}, \mathrm{H} 2 \mathrm{~B}$, and H3) was used at a concentration that gave equal binding to total histones in ELISA and equal immunofluorescence intensity on histone-conjugated sheep erythrocytes compared with MH-2. Only $18.3 \%$ of the large cells were positive with this antibody using cells after 16 to $24 \mathrm{~h}$ of culture. The intensity of fluorescence of the positive cells was also much less using MH-1 compared with MH-2 (data not shown). Table I also shows that the antiDNA antibody BWD-1 stained $35.4 \%$ of the cultured cells.

The data in Table I are presented for the large cell fraction only. None of the antibodies appeared to recognize a significant percentage of cells in the small cell fraction, either before or after culture (for BWH-1, after 16 to $24 \mathrm{~h}$ of culture, $2.5 \pm 0.4 \%$ of the small cells were positive compared with $1.2 \pm 0.2 \%$ for the control IgG2a antibody, $n=14$ ).

Anti-histone antibody binding occurs at the cell surface. It was critical to determine that the cells binding the anti-histone antibodies were viable, to thus not allow the antibody to penetrate the plasma membrane and bind to the nucleus. Viability was determined by uptake of fluorescein diacetate. After 16 to $24 \mathrm{~h}$ of culture, $96.5 \pm 1.3 \%$ of the large cells were intensely fluorescent with fluorescein diacetate $(n=10)$.

In other experiments, histone-positive cells were enriched by plastic adherence for $1 \mathrm{~h}$ (see below) and then cultured as adherent cells for $16 \mathrm{~h}$. When these cells were stained with the anti-histone antibodies BWH-1 and MH-2, intense membrane staining of $30 \%$ of the cells in the absence of nuclear staining was observed under the fluorescence microscope. Fluorescent staining was not observed using the control monoclonal antibodies.

Binding to BWH-1 is not mediated by Fc receptors. It seemed unlikely that binding of the IgM anti-histone antibodies (MH1 and $\mathrm{MH}-2$ ) was Fc receptor mediated. We wanted to determine whether BWH-1 binding was Fc receptor mediated, especially considering the likelihood of immune complex formation in the hybridoma supernatants. It should be emphasized that all IgG antibody preparations were routinely ultracentrifuged to remove aggregates or complexes before use in the experiments presented above. In several experiments, we also used the IgG monomer of BWH-1, prepared by G-200 gel filtration (22). This material (which was used at a lower IgG concentration than supernatant material) stained a large percentage of cells in the large cell fraction after culture $(32.3 \pm 1.4 \%$, compared with $41.5 \pm 4.2 \%$ $(n=3)$ for the supernatant material). We also attempted to block the binding of BWH-1 to large cells after culture by prior binding of heat-aggregated human immunoglobulin. Fig. 3 shows that unlike BWH-1, binding of this aggregated material was similar whether cells were freshly isolated or used after $23 \mathrm{~h}$ of culture. Prior incubation for $1 \mathrm{~h}$ with up to $500 \mu \mathrm{g} / \mathrm{ml}$ of aggregated Ig did not block the binding of BWH-1 (Fig. 3).

Cell surface histone antigens are predominantly present on monocytes. Table II shows that the predominant cell type in the large cell fraction is the monocyte, as determined by the $3 \mathrm{C} 10$ monoclonal antibody (25). In contrast, the majority of cells in the small cell fraction are $\mathrm{T}$ cells, as determined by the Leu-1 monoclonal antibody. There was little change in composition of the two major fractions over the 24 -h culture period. It there-

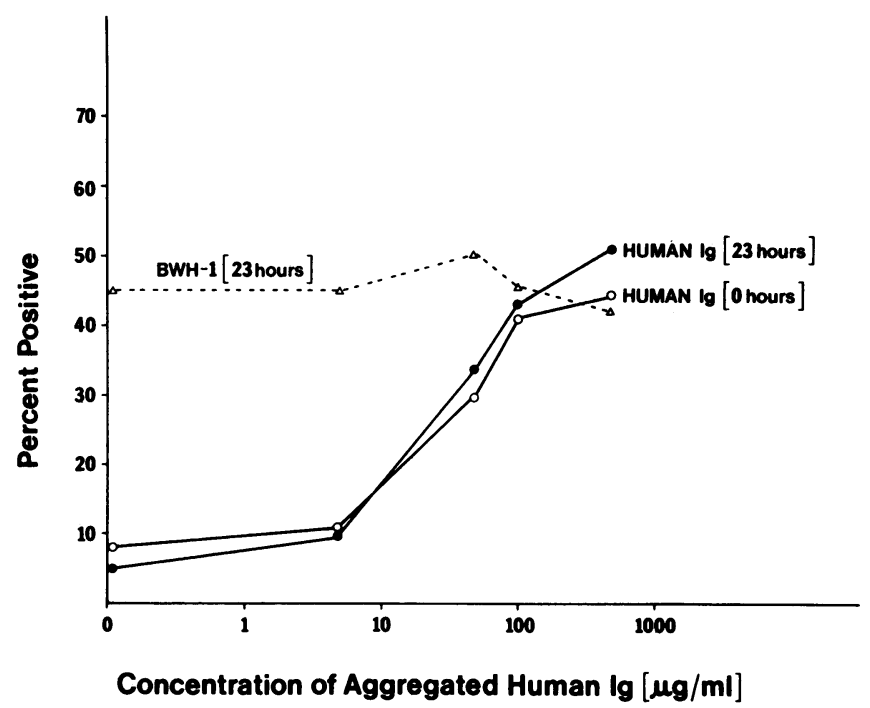

Figure 3. Binding of aggregated human Ig to the large cell fraction and effect on binding of BWH-1. PBL before culture (O) or after $23 \mathrm{~h}$ of culture (๑) were incubated with increasing amounts of aggregated human Ig for $1 \mathrm{~h}$ and then stained with a fluorescein-conjugated goat anti-human IgG reagent. PBL after culture were also stained with BWH-1 and a fluorescein-conjugated goat anti-mouse IgG reagent after incubation with the indicated concentration of aggregated human Ig $(\Delta)$. The data are presented as percentage of positive cells in the large cell fraction for one representative experiment of three.

fore seemed likely that the majority of cells bearing histone antigens after 16 to $24 \mathrm{~h}$ of culture were monocytes. To further verify this point, we obtained cells after culture and depleted cells bearing the antigens recognized by monoclonal antibodies 3C10, Leu-1, or BWH-1. Remaining cells were then analyzed by indirect immunofluorescence using these antibodies. As shown in Fig. 4, depletion of $3 \mathrm{ClO}^{+}$cells resulted in removal of most of the histone-bearing $\left(\mathrm{BWH}^{-} \mathrm{1}^{+}\right)$cells. In contrast, prior depletion of Leu- $1^{+}$cells had little effect on the percentage of BWH- $1^{+}$cells. When BWH-1 was used for complement-mediated cytotoxicity, only about half of the $\mathrm{BWH}-1^{+}$cells were depleted. This also resulted in a $50 \%$ decrease in the percentage of $3 \mathrm{ClO}^{+}$cells, but did not decrease the percentage of Leu- $1^{+}$ cells. Thus, these studies indicated that the majority of histone antigen-bearing cells are monocytes.

Although $\mathrm{T}$ cells in the small or large cell fractions did not appear to have cell surface histone or DNA antigens, it was

Table II. Percentage of T Cells (Leu-1 $1^{+}$Cells) and Monocytes $\left(3 \mathrm{ClO}^{+}\right.$Cells) Before and After Culture

\begin{tabular}{llllr}
\hline $\begin{array}{l}\text { Hours } \\
\text { in } \\
\text { culture }\end{array}$ & Cell fraction & & \multicolumn{2}{c}{ Percentage of cells positive* } \\
\hline & & $n$ & & \multicolumn{1}{c}{3 Leu-1 } \\
\hline 0 & Small & $(11)$ & $65.6 \pm 3.0$ & $4.4 \pm 1.3$ \\
0 & Large & $(14)$ & $14.3 \pm 2.8$ & $69.2 \pm 3.6$ \\
$16-24$ & Small & $(7)$ & $67.1 \pm 3.8$ & $3.0 \pm 0.8$ \\
$16-24$ & Large & $(11)$ & $20.8 \pm 2.6$ & $62.5 \pm 2.3$ \\
& & & & \\
\hline
\end{tabular}

* Data are presented as the mean \pm SE for the number $(n)$ of experiments indicated before culture and after 16 to $24 \mathrm{~h}$ of culture. 


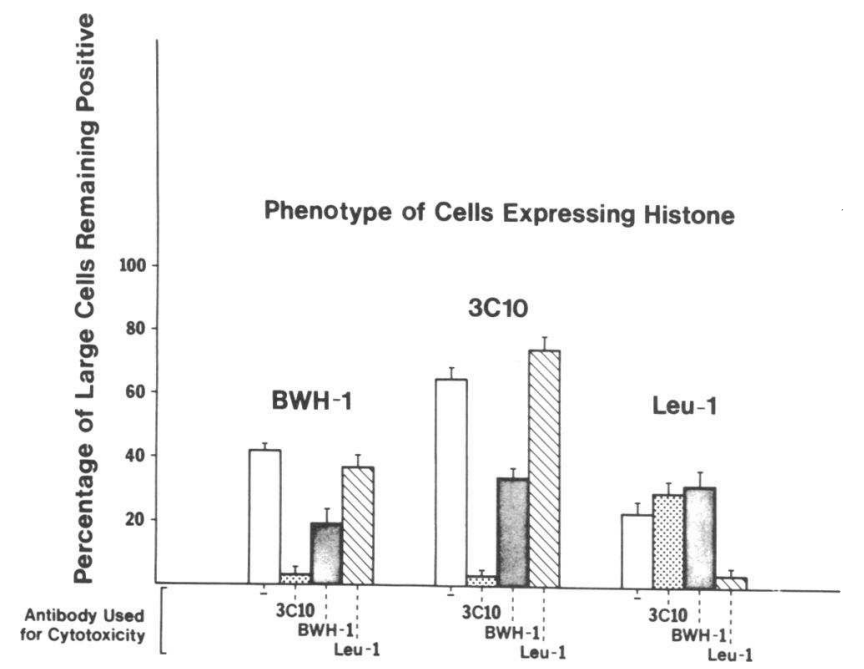

Figure 4. Phenotype of cells expressing histone. PBL after 16 to $24 \mathrm{~h}$ of culture, were treated with complement alone (open bars), $3 \mathrm{C} 10$ (which recognizes monocytes) and complement (stippled bars), BWH1 (anti-histone antibody) and complement (shaded bars), or Leu-1 (which recognizes all $\mathrm{T}$ cells) and complement (hatched bars). The cells remaining were then stained with one of these antibodies (indicated by bold type above the bars). The values are the percentage of positive cells in the large cell fraction (mean \pm SE) determined from four experiments.

possible that activated $\mathrm{T}$ cells in culture might express these antigens. Therefore, we activated PBL with PHA for 1-3 d under optimal conditions for stimulating proliferation. No increase was observed at any time point in the percentage of positive cells in the small cell fraction. Although the percentage of $T$ cells in the large cell fraction increased after PHA stimulation, the percentage of histone antigen-positive cells in the large cell fraction decreased.

We also determined whether $\mathrm{T}$ cells were required in culture for histone antigen-bearing cells to appear. PBL were rigorously depleted of Leu- $1^{+}$cells by sheep erythrocyte rosetting and complement-mediated cytotoxicity, such that $<1 \%$ of cells were Leu$1^{+}$by indirect immunofluorescence and FACS analysis. These cells were then placed into culture for $20 \mathrm{~h}$, and the percentage of large cells that bound the anti-histone antibodies was determined as described above. In one representative experiment of three, $85 \%$ of the large cells were $3 \mathrm{C}^{+} 0^{+}$, with 52 and $64 \%$ positive for BWH-1 and $\mathrm{MH}-2$, respectively, after T cell depletion. PBL in the same experiment resulted in $68 \% 3 \mathrm{C}^{+} 0^{+}$large cells, with $40 \% \mathrm{BWH}-1^{+}$and $58 \% \mathrm{MH}-2^{+}$cells. Thus, despite prior depletion of $\mathrm{T}$ cells, full expression of histone antigen-positive cells was observed.

Inhibition of histone expression by cycloheximide. Cycloheximide was added at the initiation of an 18-h culture to determine whether protein synthesis was required for histone antigen expression. Table III shows that very low amounts of cycloheximide $(0.25-0.50 \mu \mathrm{g} / \mathrm{ml})$ nearly completely eliminated the in vitro increase in histone-positive cells. In seven experiments, $0.5 \mu \mathrm{g} / \mathrm{ml}$ of cycloheximide reduced the percentage of BWH- $1^{+}$ cells from $38.7 \pm 3.2 \%$ to $2.6 \pm 0.6 \%$, and reduced $\mathrm{MH}-2^{+}$cells from $48.3 \pm 5.0 \%$ to $9.4 \pm 2.3 \%$. This reduced percentage of MH$2^{+}$cells is similar to the number of cells positive before culture (see Table I). In similar studies, DNA antigen expression was also markedly inhibited by low concentrations of cycloheximide
Table III. Inhibition of Histone Expression by Cycloheximide

\begin{tabular}{lllll}
\hline \multirow{5}{*}{ Cycloheximideł } & \multicolumn{4}{l}{ Percentage of large cells positive* } \\
\cline { 2 - 5 } & Cont-IgG2a & BWH-1 & MH-2 & 3C10 \\
\hline$\mu g / m l$ & & & & \\
0 & 3.7 & 35.8 & 40.5 & 52.3 \\
0.25 & 2.9 & 7.7 & 9.3 & 51.4 \\
0.50 & 2.1 & 2.1 & 8.5 & 43.7 \\
5.0 & 1.9 & 7.6 & 13.2 & 19.9 \\
& & & & \\
\hline
\end{tabular}

* The number of positive cells in the large cell fraction after $18 \mathrm{~h}$ of culture are indicated. The data are presented for one representative experiment of four.

$¥$ The indicated concentration of cycloheximide was added at initiation of the culture.

$(43.5 \pm 9.8 \%$ vs. $8.2 \pm 3.0 \%$ positive cells with $0.25 \mu \mathrm{g} / \mathrm{ml}$ cycloheximide).

In kinetic experiments, progressively less inhibition of histone expression was observed if the addition of cycloheximide was delayed until after initiation of culture. When cycloheximide was added after $12 \mathrm{~h}$ of culture, no inhibition was observed. The decreased percentage of positive cells with low cycloheximide concentrations was not a result of depletion of monocytes $\left(3 \mathrm{C} 10^{+}\right.$ cells) from the large cell fraction (Table III). Furthermore, in other experiments, the effects of cycloheximide were demonstrated to be reversible. Cells were placed in culture with cycloheximide $(0.25 \mu \mathrm{g} / \mathrm{ml})$, which was then washed out after 12 to $16 \mathrm{~h}$ of culture. The cells were then cultured for an additional $24 \mathrm{~h}$. Appearance of histone antigen-positive cells after wash out of the cycloheximide was similar to the kinetics shown in Fig. 2 . When cells were cultured with higher cycloheximide concentrations (i.e., $5 \mu \mathrm{g} / \mathrm{ml}$ ), a reduction in the percentage of both histone antigen-positive and $3 \mathrm{C}^{+} 0^{+}$cells was observed (Table III). None of the concentrations tested had an effect on the percentage of Leu- $1^{+}$cells in the small cell fraction (data not shown).

Table IV. Effect of Gamma Irradiation on Histone Expression in Culture*

\begin{tabular}{|c|c|c|c|c|c|}
\hline \multirow{2}{*}{$\begin{array}{l}\text { Irradiation } \\
\text { doseł }\end{array}$} & \multicolumn{2}{|c|}{$\begin{array}{l}\text { Percentage of } \\
\text { large cells } \\
\text { positive* }\end{array}$} & \multirow{2}{*}{$\begin{array}{l}\text { Percentage of } \\
\text { remaining cells in } \\
\text { large cell fraction }\end{array}$} & \multirow{2}{*}{$\begin{array}{l}\text { Viability } \\
\text { of large cells§ }\end{array}$} & \multirow{2}{*}{$\begin{array}{l}\text { Viability } \\
\text { of total cells§ }\end{array}$} \\
\hline & BWH-1 & MH-2 & & & \\
\hline \multicolumn{6}{|l|}{$\mathrm{rad}$} \\
\hline 0 & 46.8 & 78.1 & 8.7 & 98 & 83 \\
\hline 500 & 51.0 & 69.7 & 9.2 & 98 & 75 \\
\hline 1,000 & 50.1 & 68.3 & 10.7 & 98 & 64 \\
\hline 2,000 & 40.0 & 60.1 & 5.2 & 98 & 54 \\
\hline 3,000 & 53.7 & 60.3 & 6.1 & 98 & 47 \\
\hline 6,000 & 46.0 & 73.1 & 3.7 & 96 & 16 \\
\hline
\end{tabular}

* The percentage of positive cells in the large cell fraction after $18 \mathrm{~h}$ of culture are indicated. Data are presented for one representative experiment of three.

¥ PBL were irradiated to the indicated dose immediately before being placed into culture.

$\S$ Viability was determined by uptake of fluoresceine diacetate. 
Effect of gamma irradiation on histone expression in culture. In contrast to the inhibition observed with low concentrations of cycloheximide, little effect on histone antigen expression in culture was detected after in vitro gamma irradiation. Table IV shows a high percentage of positive cells in the large cell fraction detected by antibodies BWH-1 and MH-2 even after 2,000 to 6,000 rad of irradiation. These doses resulted in a progressive decrease in the total viability of remaining cells after culture, and some loss of cells from the large cell fraction (Table IV). Although the total viability of the cultured cells decreased from 83 to $16 \%$ after $6,000 \mathrm{rad}$, the viability of the large cell fraction (the fraction analyzed for histone expression) remained $>95 \%$.

\section{Discussion}

We noted that monoclonal anti-histone and anti-DNA antibodies bound to a subset of PBL (obtained from normal individuals), especially after cell culture. The positive cells were shown to be viable monocytes, and the antibodies could be shown to be binding in a saturable manner to the cell surface and not to the nucleus. Two of the anti-histone antibodies used, including the strongest reactor, were IgM, and thus Fc receptor-mediated binding did not seem likely (30). We also showed that the marked increase in positive cells after 12 to $16 \mathrm{~h}$ of culture was not paralleled by a similar kinetic change in Fc receptor-mediated binding of aggregated human Ig. In addition, the binding of the IgG2a monoclonal antibody BWH-1 was not blocked by prior incubation with aggregated human Ig. Although a separate Fc receptor for mouse IgG2a has been reported on human monocytes, a major increase in this receptor does not seem likely during the short period of our cultures $(31,32)$. We also used control IgG2a monoclonal antibodies in every experiment that did not show a similar increase in binding compared with BWH1. We were not able to obtain adequate amounts of the $F\left(a b^{\prime}\right)_{2}$ fragment of BWH-1 after pepsin digestion despite using conditions successfully utilized for other murine IgG2a monoclonal antibodies $(33,34)$. A lower molecular weight fragment corresponding to the Fab' monomer was obtained but bound to cultured monocytes poorly ( $<10 \%$ above control values), possibly reflecting a low affinity of BWH-1 for the cell surface antigen (34). We did prepare the IgG monomer by gel filtration, which stained cells similar to supernatant material. The above data strongly suggest that binding of the different monoclonal ANA to monocyte cell surfaces after cell culture was not secondary to Fc receptor-mediated binding. Furthermore, the binding of the IgG monomer of BWH-1 implies that antibody binding to cells was not the result of histone present in antigen-antibody complexes.

Only one anti-histone antibody (MH-2) bound to freshly isolated cells. Compared with after culture, a lower percentage of cells was detected, and these cells were of relatively low fluorescence intensity. MH-2 showed the strongest binding activity after culture compared with the other antibodies used. Thus, binding to freshly isolated PBL by only MH-2 may be secondary to its greater sensitivity of detection. After 16 to $24 \mathrm{~h}$ of culture, positive cells were detected using one anti-DNA and three different anti-histone monoclonal antibodies. These antibodies recognize separate antigenic determinants on chromatin and histones extracted from chromatin (22). One antibody (BWH1) does not bind to any of the individual histones $(\mathrm{H} 1, \mathrm{H} 2 \mathrm{~A}$, $\mathrm{H} 2 \mathrm{~B}, \mathrm{H} 3$, or $\mathrm{H} 4$ ), but recognizes a determinant formed after the interaction of histones $\mathrm{H} 2 \mathrm{~A}$ and $\mathrm{H} 2 \mathrm{~B}$ (22). This determinant is present in high concentration in the nucleosome core of chromatin. The above data suggest that these anti-nuclear antibodies are not binding to the cell surface by chance cross-reactive determinants, but rather are binding to a chromatinlike material on the cell surface. Antibodies $\mathrm{MH}-1$ and $\mathrm{MH}-2$ were used at concentrations that gave equal binding to chromatin in ELISA and equal binding to histone-conjugated sheep erythrocytes by immunofluorescence. However, $\mathrm{MH}-2$ recognized a much greater percentage of large cells as well as stained with considerably greater fluorescence intensity. This may indicate that there are significant differences between the surface material and intact chromatin. We are presently attempting to surface label and immunoprecipitate the cell surface material recognized by the different antibodies.

The mechanisn of in vitro expression of nuclear antigenic material may be related to: $(a)$ the accumulation of supernatant nuclear material with subsequent binding to resting monocytes; (b) in vitro monocyte transformation or activation with subsequent binding of exogenous supernatant material or surface expression of this material after intracellular uptake; and $(c)$ in vitro monocyte transformation or activation with surface presentation of endogenous nuclear antigens. The in vitro increase in positive cells was nearly completely inhibited by low concentrations of cycloheximide, indicating that protein synthesis is required for the appearance of both DNA and histone on the cell surface. Furthermore, the effects of cycloheximide were reversible, and the kinetics of increase of positive cells after wash out were similar to those of freshly cultured cells (requiring 12$16 \mathrm{~h}$ for full expression). More recent experiments indicate that cycloheximide does not decrease the accumulation of supernatant chromatinlike material (unpublished observations). These data are consistent with the hypothesis that monocyte transformation in culture is necessary for the full appearance of cell surface nuclear antigens. Results showing the resistance to gamma irradiation are also consistent with this hypothesis, considering the radioresistance of many other monocyte functions. Studies are in progress to determine whether monocyte expression involves synthesis of a receptor for exogenous nuclear material or the placement of endogenously synthesized nuclear antigens on the cell surface. It is possible that the few cells that are histone positive in the circulation have been activated in vivo, and that a large percentage of monocytes/macrophages are positive in vivo after migration to different tissues.

There have been several previous reports suggesting that cell surface membranes are associated with histone and DNA antigenic material. Rekvig and Hannestad (18-21) characterized antibodies obtained from the sera of patients with systemic lupus erythematosus that reacted with both plasma membranes and nuclei. The "cross-reactive anti-nuclear antibodies" displayed specificity for the octomer of histones present in core mononucleosomes but not for free histone or free DNA. In contrast to our studies, nearly all nucleated cells (freshly isolated or cultured) were found to bind these antibodies, presumably at the cell surface. Other investigators have successfully extracted DNA from the plasma membrane of cultured human lymphocytes (14-15). Labeling studies and kinetic renaturation studies indicated that membrane associated DNA was not likely to be a contaminant of nuclear or mitochondrial origin. In more recent studies, Bennett and colleagues $(16,17)$ noted that lactoferrin bound to freshly isolated PBL, and that this binding was mediated by membrane DNA. Interestingly, the greatest binding was ob- 
served with adherent mononuclear cells, while no binding to $T$ cells was detected. These investigators also showed that lactoferrin binding was markedly increased after stimulation in culture with endotoxin for $7 \mathrm{~d}$.

The presence of cell surface nuclear antigens raises interesting questions regarding SLE and other lupuslike diseases. ANA in these patients could result in selective cell damage, depending on which nuclear antigens are present on the cell surface. Recently, it was shown that epidermal cells damaged by ultraviolet irradiation displayed surface nuclear antigens SS-A/Ro, ribonucleoprotein, and Sm without developing membrane permeability to antibodies (35). These cells did not express histone or DNA. Antibodies to SS-A/Ro have been associated with photosensitivity and skin rash in SLE (7-9), perhaps by binding to SS-A antigen on epidermal cells in vivo. It is conceivable that expression of histone and DNA on monocytes could result in monocyte injury or dysfunction in patients with circulating antibodies to these antigens. Monocyte (macrophage) abnormalities have been reported in SLE (36-39). It is also difficult to overlook the fact that monocytes are potential antigen presenting cells. It is presently unknown why certain patients produce particular ANA in large quantities, in some cases to the apparent exclusion of other ANA or other autoantibodies. We are currently investigating the possibility that histone and DNA present on monocyte surfaces are immunogenic, and are involved in the expansion of particular ANA or even the maintenance of tolerance in normal individuals.

\section{Acknowledgments}

The authors acknowledge Ronald Arndt for expert technical assistance, David Fogleman for help in performing analyses on the fluorescenceactivated cell sorter, Louise Greene and Inez Curiel for help in preparing the manuscript, and Dr. William P. Arend for helpful discussions regarding the manuscript.

This work was supported in part by a grant from the Veterans Administration and grant BRSG-05357, awarded by the Biomedical Research Grant Program, Division of Research Resources, National Institutes of Health.

\section{References}

1. Koffler, D., P. H. Schur, and H. G. Kunkel. 1967. Immunological studies concerning the nephritis of systemic lupus erythematosus. J. Exp. Med. 126:607-624.

2. Koffler, D., and H. G. Kunkel. 1968. Mechanisms of renal injury in systemic lupus erythematosus. Am. J. Med. 45:165-168.

3. Koffler, D., V. Agnello, and H. G. Kunkel. 1974. Polynucleotide immune complexes in serum and glomeruli of patients with systemic lupus erythematosus. Am. J. Pathol. 74:109-124.

4. Tan, E. M. 1982. Autoantibodies to nuclear antigens (ANA): their immunobiology and medicine. Adv. Immunol. 33:167-240.

5. Sharp, G. C., W. S. Irvin, C. M. May, H. R. Holman, F. C. McDuffy, E. V. Hess, and F. R. Schmid. 1976. Association of antibodies to ribonucleoprotein and $\mathrm{Sm}$ antigens with mixed connective-tissue disease, systemic lupus erythematosus and other rheumatic diseases. $N$. Engl. J. Med. 295:1149-1154.

6. Sharp, G. C., W. S. Irvin, E. M. Tan, R. G. Gould, and H. R. Holman. 1972. Mixed connective tissue disease-an apparently distinct rheumatic disease syndrome associated with specific antibody to an extractable nuclear antigen (ENA). Am. J. Med. 52:148-159.

7. Weston, W. L., C. Harmon, C. Peebles, D. Manchester, H. L. Franco, J. C. Huff, and D. A. Norris. 1982. A serological marker for neonatal lupus erythematosus. Br. J. Dermatol. 107:377-382.
8. Sontheimer, R. D., P. J. Maddison, M. Reichlin, R. E. Jordon, P. Stastny, and J. N. Gilliam. 1982. Serologic and HLA associations in subacute cutaneous lupus erythematosus, a clinical subset of lupus erythematosus. Ann. Intern. Med. 97:664-671.

9. Maddison, P. J., T. T. Provost, and M. Reichlin. 1981. Serologic findings in patients with "ANA negative" systemic lupus erythematosus. Medicine. 60:87-94.

10. Fritzler, M. J., and E. M. Tan. 1978. Antibodies to histones in drug induced and idiopathic lupus erythematosus. J. Clin. Invest. 62 : 560-567.

11. Tan, E. M., G. P. Rodnan, I. Garcia, Y. Moroi, M. J. Frizler, and C. Peebles. 1980. Diversity of antinuclear antibodies in progressive systemic sclerosis: anti-centromere antibody and its relationship to CREST Syndrome. Arthritis Rheum. 23:617-625.

12. Fritzler, M. J., T. D. Kinsella, and E. Garbutt. 1980. The CREST syndrome: a distinct serologic entity with anticentromere antibodies. Am. J. Med. 69:520-526.

13. Alarcon-Segovia, D., A. Ruiz-Arguelles, and E. Fishbein. 1978. Antibody to nuclear ribonucleoprotein penetrates live human mononuclear cells through Fc receptors. Nature (Lond.). 271:67-69.

14. Meinke, W., M. R. Hall, D. A. Goldstein, D. E. Kohne, and R. A. Lerner. 1973. Physical properties of cytoplasmic membrane-associated DNA. J. Mol. Biol. 78:43-56.

15. Reid, B. L., and A. J. Charlson. 1979. Cytoplasmic and cell surface deoxyribonucleic acids with consideration of their origin. Int. Rev. Cytol. 60:27-52.

16. Bennett, R. M., and J. Davis. 1981. Lactoferrin binding to human peripheral blood cells: an interaction with a B-enriched population of lymphocytes and a subpopulation of adherent mononuclear cells. J. Immunol. 127:1211-1215.

17. Bennett, R. M., J. Davis, S. Campbell, and S. Portnoff. 1983. Lactoferrin binds to cell membrane DNA. Association of surface DNA with an enriched population of B cells and monocytes. J. Clin. Invest. 71:611-618.

18. Rekvig, O. P., and K. Hannestad. 1977. Certain polyclonal antinuclear antibodies cross-react with the surface membrane of human lymphocytes and granulocytes. Scand. J. Immunol. 6:1041-1054.

19. Rekvig, O. P., and K. Hannestad. 1979. Properties of antinuclear antibodies that cross-react with plasma membranes. Scand. J. Immunol. 9:325-332.

20. Rekvig, O. P., and K. Hannestad. 1979. The specificity of human autoantibodies that react with both cell nuclei and plasma membranes: the nuclear antigen is present on core mononucleosomes. J. Immunol. 123:2673-2681.

21. Rekvig, O. P., and K. Hannestad. 1980. Human autoantibodies that react with both cell nuclei and plasma membranes display specificity for the octamer of histones H2A, H2B, H3, and H4 in high salt. J. Exp. Med. 152:1720-1733.

22. Kotzin, B. L., J. A. Lafferty, J. P. Portanova, R. L. Rubin, and E. M. Tan. 1984. Monoclonal anti-histone autoantibodies derived from murine models of lupus. J. Immunol. 133:2554-2559.

23. Boyum, A. 1968. Isolation of mononuclear cells and granulocytes from human blood. Scand. J. Clin. Lab. Invest. 21(Suppl. 97):77-89.

24. Engleman, E. G., R. Warnke, R. I. Fox, J. Dilley, C. Benike, and R. Levy. 1981. Studies of a human T lymphocyte antigen recognized by a monoclonal antibody. Proc. Natl. Acad. Sci. (USA). 78:1791-1795.

25. Van Voorhis, W. C., R. M. Steinman, L. S. Hair, J. Luban, M. D. Witmer, S. Koide, and Z. A. Cohn. 1983. Specific antimononuclear phagocyte monoclonal antibodies. Application to the purification of dendritic cells and the tissue localization of macrophages. J. Exp. Med. 158:126-146.

26. Herzenberg, L. A., and L. A. Herzenberg. 1978. Analysis and separation using the fluorescence-activated cell sorter (FACS). In Handbook of Experimental Immunology. D. M. Weir, editor. Blackwell, Oxford. Third ed. 22.1-22.21.

27. Kotzin, B. L., G. S. Kansas, E. G. Engleman, R. T. Hoppe, H. S. Kaplan, and S. Strober. 1983. Changes in T-cell subsets in patients 
with rheumatoid arthritis treated with total lymphoid irradiation. Clin. Immunol. Immunopathol. 27:250-260.

28. Mishell, B. B., S. M. Shiigi, C. Henry, E. L. Chan, J. North, R. Gallily, M. Slomich, K. Miller, J. Marbrook, D. Parks, and A. H. Good. 1980. Preparation of mouse cell suspensions. In Selected Methods in Cellular Immunology. B. B. Mishell and S. M. Shiigi, editors. W. H. Treeman and Co., San Francisco. 19-21.

29. Portanova, J. P., B. L. Kotzin, E. A. Coleman, and H. N. Claman. 1984. Distribution of anti-histone antibody secreting cells in NZB/NZW mice. Cell. Immunol. 87:485-493.

30. Leslie, R. G. Q., and M. D. Alexander. 1979. Cytophilic antibodies. Curr. Top. Microbiol. Immunol. 88:25-104.

31. Perussia, B., E. T. Dayton, R. Lazarus, V. Fanning, and G. Trinchieri. 1983. Immune interferon induces the receptor for monomeric IgG1 on human monocytic and myeloid cells. J. Exp. Med. 158:10921113.

32. Steplewski, Z., M. D. Lubeck, and H. Koprowski. 1983. Human macrophages armed with murine immunoglobulin G2a antibodies to tumors destroy human cancer cells. Science (Wash. DC). 221:865-867.

33. Lamoyi, E., and A. Nisonoff. 1983. Preparation of $F\left(a b^{\prime}\right)_{2}$ frag- ments from mouse IgG of various subclasses. J. Immunol. Methods. 56 235-243.

34. Parham, P. 1983. On the fragmentation of monoclonal IgGl, IgG2a, and IgG2b from BALB/c mice. J. Immunol. 131:2895-2902.

35. LeFeber, W. P., D. A. Norris, S. R. Ryan, J. C. Huff, L. A. Lee, M. Kubo, S. T. Boyce, B. L. Kotzin, and W. L. Weston. 1984. Ultraviolet light induces expression of selected nuclear antigens on cultured human keratinocytes. J. Clin. Invest. 74:1545-1551.

36. Alcocer-Varela, J., A. Laffon, and D. Alarcon-Segovia. 1983. Defective monocyte production of, and $\mathrm{T}$ lymphocyte response to, interleukin-1 in the peripheral blood of patients with systemic lupus erythematosus. Clin. Exp. Immunol. 54:125-132.

37. Kavai, M., K. Lukacs, I. Sonkoly, K. Paloczi, and Gy. Szegedi. 1979. Circulating immune complexes and monocyte $\mathrm{Fc}$ function in autoimmune diseases. Ann. Rheum. Dis. 38:79-83.

38. Svensson, B. O. 1975. Serum factors causing impaired macrophage function in systemic lupus erythematosus. Scand. J. Immunol. 4:145150.

39. Kavai, M., A. Zsindely, I. Sonkoly, M. Major, I. Demjan, and Gy. Szegedi. 1983. Signals of monocyte activation in patients with SLE. Clin. Exp. Immunol. 51:255-260. 